\title{
Marian Oliński
}

\section{MOTYWY PODEJMOWANIA DZIAŁALNOŚCI GOSPODARCZEJ WŚRÓD STUDENTÓW}

Zarys treści. Opracowanie dotyczy przedsiębiorczości akademickiej i prezentuje wybrane zależności, które mają określony wpływ (charakteryzujący się różną siłą oddziaływania) na podejście i zamierzenia respondentów, będących studentami Uniwersytetu Warmińsko-Mazurskiego, odnośnie do prowadzenia własnego przedsiębiorstwa. Głównym celem przeprowadzonych badań empirycznych, których rezultaty są tu omawiane, była identyfikacja czynników mających wpływ na podjęcie decyzji o założeniu własnej firmy, jak też zdiagnozowanie nastawienia potencjalnych przedsiębiorców do prowadzenia własnego biznesu.

Słowa kluczowe: przedsiębiorczość akademicka.

\section{WPROWADZENIE}

Tematyka przedsiębiorczości akademickiej stała się w ostatnich latach bardzo popularna. Niektórzy autorzy wskazują na przełom, jaki obecnie dokonuje się w szkołach wyższych - mowa jest o tzw. uniwersytecie trzeciej generacji, który w odróżnieniu od uniwersytetu humboldtowskiego (drugiej generacji), obok nauki i dydaktyki, kładzie również nacisk na komercjalizację badań i pełnienie roli centrów transferu technologii (Wissema, 2005, s. 21). Prawidłowa realizacja tej dodatkowej funkcji wymaga jednak zmian w sposobie myślenia środowisk akademickich i ukształtowania swoistej „kultury przedsiębiorczości” zarówno wśród pracowników naukowych, jak i studentów. Do tego z kolei niezbędna jest edukacja z zakresu przedsiębiorczości akademickiej. Dlatego też w ostatnich kilkudziesięciu latach w krajach wysoko rozwiniętych można było zaobserwować tendencję do włączania do programów szkół wyższych wszystkich typów, 
specjalistycznych programów edukacyjnych w dziedzinie przedsiębiorczości (Cieślik, Matusiak, Guliński, Skala-Poźniak, 2011, s. 41). W ślad za rozwijaniem programów edukacyjnych w zakresie przedsiębiorczości akademickiej podążyła literatura naukowa zarówno obcojęzyczna (np. Althaus, 2009; Wright, Clarysse, Mustar, Lockett, 2007; Kuratko, 2004; Katz, 2003), jak i polska (np. Cieślik, 2008; Matusiak, 2010; Barski, Cook, 2011). Oczywiście wraz z publikacjami związanymi z edukacją przedsiębiorczości w szkołach wyższych przeprowadzono liczne badania dotyczące stanu i kierunków rozwoju tejże przedsiębiorczości. Przytoczyć tu można legendarny już Bank Boston Report. W opracowaniu tym podano informację, która zaszokowała środowisko naukowe. Stwierdzono, że gdyby firmy założone przez absolwentów i wykładowców Massachusetts Institute of Technology utworzyły niezależny naród, to dochód wytworzony przez te firmy uplasowałby ten naród na 24 pozycji wśród największych gospodarek świata (Departament Finansowy Bank Boston, 1997, cyt. za Wissema, 2005). Również w Polsce pojawiają się publikacje, które z jednej strony diagnozują stan przedsiębiorczości akademickiej, a z drugiej wskazują kierunki jej rozwoju. Jedna $\mathrm{z}$ bardziej kompleksowych diagnoz $\mathrm{w}$ tym temacie przedstawiona została w publikacji przygotowanej na zlecenie Polskiej Agencji Rozwoju Przedsiębiorczości, zatytułowanej Przedsiębiorczość akademicka. Raport z badań (Banerski, Gryzik, Matusiak, Mażewska, Stawasz 2009). Niniejszy artykuł również prezentuje wybrane zależności (czynniki), które mają określony wpływ (charakteryzujący się różną siłą oddziaływania) na podejście i zamierzenia respondentów odnośnie do prowadzenia własnego przedsiębiorstwa. Celem przeprowadzonych badań była identyfikacja czynników mających wpływ na podjęcie decyzji o założeniu własnej firmy oraz zdiagnozowanie nastawienia potencjalnych przedsiębiorców do prowadzenia własnego biznesu.

\section{METODYKA BADAŃ}

W ramach projektu „wSPINaj się! - Portal Innowacyjny” (dofinansowanego z Europejskiego Funduszu Społecznego w ramach Programu Operacyjnego Kapitał Ludzki) przeprowadzono badania dotyczące zamierzeń studentów co do zakładania i prowadzenia własnej firmy. Ogółem badaniu ankietowemu poddano losowo dobraną próbę 67 osób-studentów Uniwersytetu Warmińsko-Mazurskiego w Olsztynie, którzy wzięli udział w kursie e-learningowym, dotyczącym tematyki przedsiębiorczości akademickiej. Była to grupa osób studiujących w systemie niestacjonarnym. Wyboru takiego dokonano świadomie. Wiadomo bowiem, że wśród studentów niestacjonarnych przeważają osoby aktywne zawodowo lub takie, które miały jakikolwiek ,kontakt z praktyką”. Uzyskanie opinii 
od tak dobranej grupy respondentów wydaje się szczególnie cenne. Osoby te powinny być mniej skłonne (w porównaniu ze studentami dziennymi) do fantazjowania na temat zakładania własnego biznesu, a praktyka zawodowa pozwala im lepiej ocenić własne umiejętności i możliwości „bycia na swoim”. Badania przeprowadzono w maju 2011 roku, wykorzystując w tym celu metodę ankiety bezpośredniej.

Ponad 65\% przebadanych osób często lub czasami myślała o założeniu własnej firmy (rys. 1). Od chęci do realizacji jest jeszcze długa droga, jednakże dane te dowodzą, że potencjał i energia wśród studentów uniwersytetu są duże. Oczywiście, aby ten potencjał odpowiednio „zagospodarować”, muszą być, po pierwsze, stworzone odpowiednie warunki dla rozwoju przedsiębiorczości, po drugie, oprócz chęci zostania przedsiębiorcą, potencjalni kandydaci muszą mieć odpowiednie umiejętności, wiedzę i gotowość do ciężkiej pracy - słowem - jeśli własną przygodę z przedsiębiorczością chcą uwieńczyć sukcesem, muszą mieć „co” sprzedać i mieć pomysł ,jak to” sprzedać.

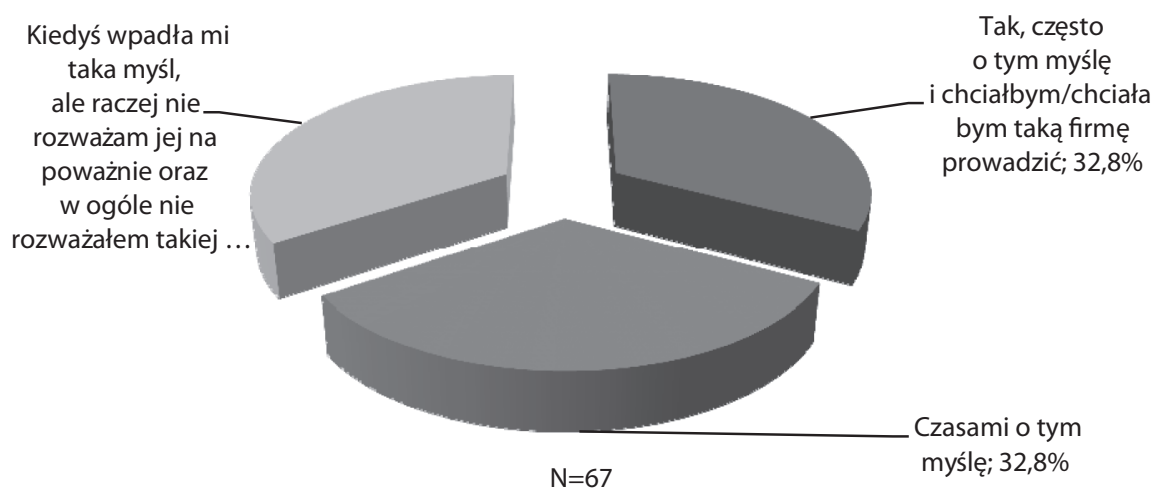

Rysunek 1. Rozważania o założeniu i prowadzeniu własnej firmy (ewentualnie jako wspólnik w spółce) jako sposobie na przyszłe zawodowe życie

Źródło: opracowanie własne na podstawie przeprowadzonych badań.

W zależności od tego, jak respondenci odpowiedzieli na pytanie dotyczące częstotliwości własnych rozważań odnośnie do założenia własnej firmy, skonstruowane zostały różne warianty kwestionariuszy ankietowych. Dla respondentów zdecydowanych na założenie własnej działalności gospodarczej skonstruowano dwa warianty kwestionariusza:

- wariant A dla tych, którzy odpowiedzieli: „tak, często o tym myślę i chciałbym/chciałabym taką firmę prowadzić";

- wariant B dla tych, którzy „,czasami o tym myślą”. 


\section{Czynniki wpływające na intencję zalożenia firmy}

Płeć. Jeśli chodzi o różnice w podejściu do prowadzenia własnego biznesu w zależności od płci, nadmienić należy, że żaden mężczyzna nie zaznaczył odpowiedzi „nigdy nie rozważałem założenia własnej firmy”. Mężczyźni dominują także (oczywiście relatywnie - biorąc pod uwagę różne liczebności obu grup) w wariancie: „Czasami o tym myślę” (rys. 2).

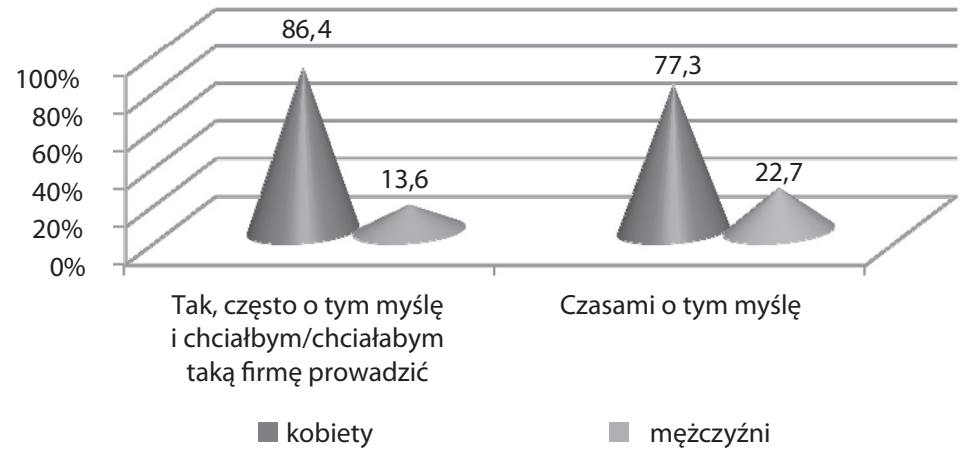

Rysunek 2. Rozważania o założeniu własnej działalności gospodarczej w zależności od płci

Źródło: opracowanie własne na podstawie przeprowadzonych badań.

Wiek. Nie należy sugerować się jedynie „wysokością słupków” (rys. 3), bowiem zarówno w próbie badawczej (jak i w całej populacji kursantów) dominowały osoby w wieku pomiędzy 20-30 lat. Co ciekawe, relatywnie bardzo wysoki odsetek odpowiedzi o częstym rozważaniu założenia własnej firmy jest wśród osób „dekadę starszych”, a więc wśród grupy osób pomiędzy 31-40 lat. Jest to obiecująca tendencja, bowiem ludzie ci charakteryzują się, z jednej strony, wyższym poziomem doświadczenia i wiedzy praktycznej (w stosunku do swych młodszych kolegów), a z drugiej strony są na tyle młodzi, że łatwiej mogą podjąć wyzwania i zmiany, jakie realizacja tych wyzwań spowoduje w ich życiu osobistym i zawodowym (tu z kolei mówimy o porównaniu ze starszymi respondentami). Nie znaczy to oczywiście, że wiek ten jest najlepszy do założenia i prowadzenia własnej firmy - takiego wieku po prostu nie ma i nie można go arbitralnie ustalić. Wiadomo, że zdobywanie doświadczenia i wiedzy, pojawienie się sprzyjających okoliczności i szereg innych czynników wpływa na wybór indywidualnej drogi życiowej każdej jednostki - nie jest to wyłącznie kwestia wieku. 


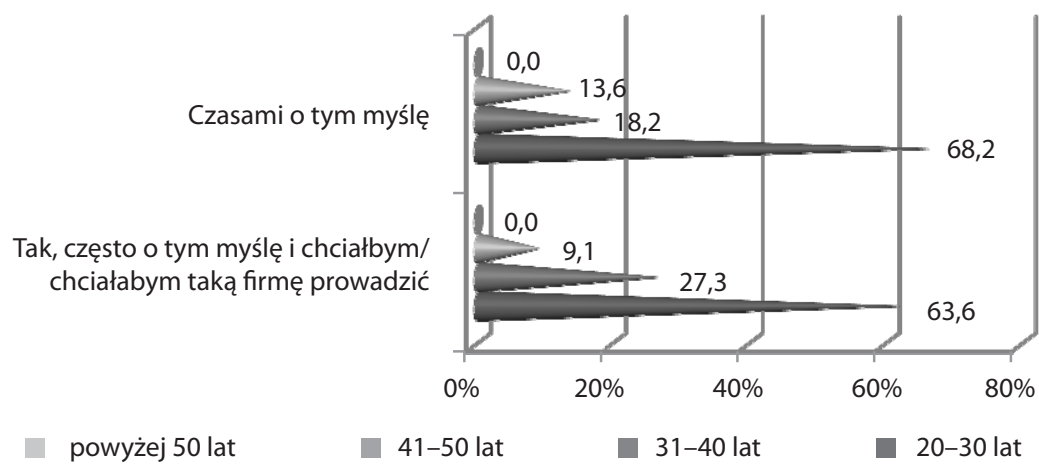

Rysunek 3. Rozważania o założeniu własnej działalności gospodarczej w zależności od wieku

Źródło: opracowanie własne na podstawie przeprowadzonych badań.

Aktywność zawodowa. Przeprowadzone badania miały na celu również ocenę zależności pomiędzy częstotliwością rozważań o założeniu własnej firmy a aktywnością zawodową respondentów (rys. 4). Co ciekawe, wariantu „często o tym myślę" nie zaznaczyła żadna z osób nieaktywnych zawodowo. Tylko osoby aktywne zawodowo zdecydowanie często myślą o założeniu i prowadzeniu własnej działalności gospodarczej. Wytłumaczyć to zjawisko można w prosty sposób. W przypadku osób pracujących mamy do czynienia z ludźmi o ustabilizowanej sytuacji i jasnych poglądach na temat przyszłych dróg kariery zawodowej - osoby te wybierały więc warianty skrajne, co jest przejawem braku wahań i wątpliwości. Natomiast druga grupa (wariant „czasami o tym myślę”) jest mniej

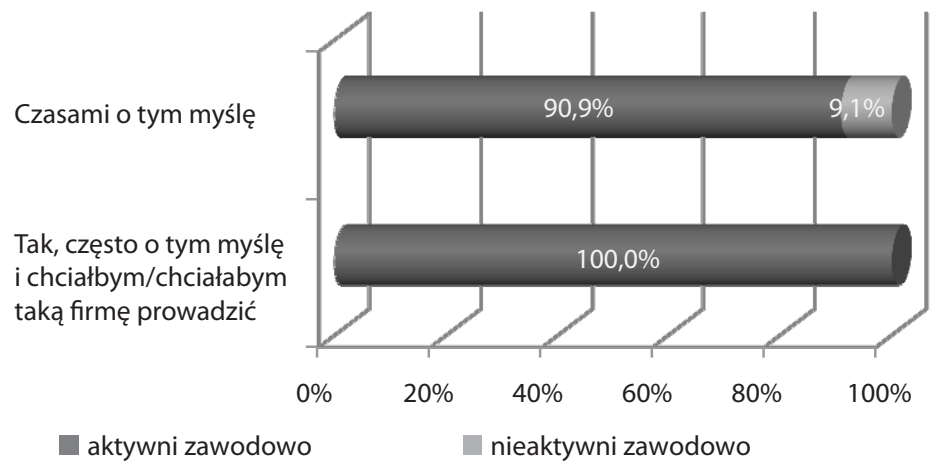

Rysunek 4. Rozważania o założeniu własnej działalności gospodarczej w zależności od aktywności zawodowej

Źródło: opracowanie własne na podstawie przeprowadzonych badań. 
zdeterminowana do zmian. Jednak sam fakt rozważania takiego kroku oznaczać może, iż osoby aktywne zawodowo są świadome własnych umiejętności i kwalifikacji, jakie zdobyły w trakcie pracy i mogą je z powodzeniem wykorzystać przy prowadzeniu własnej działalności gospodarczej. Natomiast osoby nieaktywne zawodowo są na tyle zdeterminowane własną sytuacją życiową, że myśląc o jej zmianie, jedną z dróg poprawy sytuacji upatrują w założeniu własnego przedsiębiorstwa.

Abstrahując od zależności występujących pomiędzy częstotliwością rozważań dotyczących założenia własnej firmy a poszczególnymi zmiennymi, ciekawym zagadnieniem są okoliczności towarzyszące pojawianiu się takich rozważań. Zdecydowanie dominuje tu odpowiedź, że pomysły założenia własnego przedsiębiorstwa pojawiły się $\mathrm{w}$ trakcie rozmów prowadzonych $\mathrm{z}$ rodziną lub znajomymi. Ta odpowiedź z prawie $56 \%$ udziałem wyraźnie zdominowała inne odpowiedzi (rys. 5).

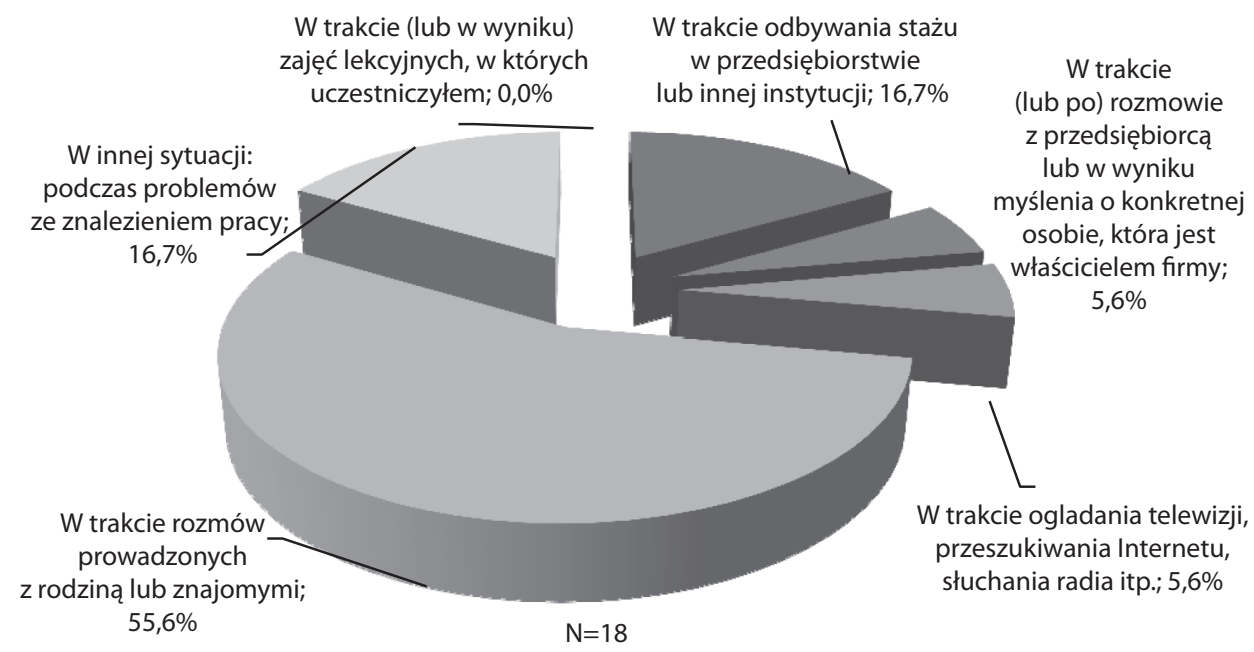

Rysunek 5. Okoliczności pojawienia się myśli o założeniu własnej firmy

Źródło: opracowanie własne na podstawie przeprowadzonych badań.

Może to się wydawać nietypowe, bowiem bardziej „naturalnymi” odpowiedziami skłaniającymi do takich rozmyślań powinny być choćby dwa kolejne najczęściej wymieniane motywy, a mianowicie: „podczas problemów ze znalezieniem pracy" i „,w trakcie odbywania stażu w przedsiębiorstwie lub innej instytucji” (obie odpowiedzi uzyskały taką samą liczbę wskazań). Wiadomo, że częstym powodem zakładania działalności gospodarczej jest „przymus 
ekonomiczny", tzn. sytuacja, w której sami próbujemy stworzyć sobie miejsce pracy, z powodu braku innej alternatywy. Podobnie kontakt z praktyką $\mathrm{w}$ trakcie odbywania stażu powinien sprzyjać przedsiębiorczym postawom i planom. Jednakże te dwa motywy, nawet łącznie nie osiągnęły zbliżonej liczby wskazań jak „rozmowy z rodziną".

Ważna jest także kwestia wyboru rodzaju prowadzonej działalności. Zaznaczyć należy, iż osoby, które odpowiedziały: „czasami o tym myślę”, zapytano najpierw, czy w ogóle mają sprecyzowany rodzaj działalności gospodarczej, który chcieliby prowadzić. Na tak postawione pytanie, większość respondentów odpowiedziała, że nie (54,5\% odpowiedzi). Dlatego, jeśli chodzi o konkretny rodzaj działalności rozważany przez potencjalnych przedsiębiorców - uwzględniano tu tylko odpowiedzi respondentów, którzy często myślą o założeniu własnej firmy, oraz respondentów, którzy czasami myślą o założeniu własnej firmy i mają przy tym sprecyzowany rodzaj działalności. Wśród preferencji dominuje tradycyjna działalność usługowa (np. handlowa, doradcza). Fakt ten wydaje się naturalny. Działalność taka związana jest $\mathrm{z}$ o wiele mniejszymi kosztami w porównaniu $\mathrm{z}$ innymi rodzajami działalności (np. działalnością produkcyjną). Poza tym tego rodzaju działalność dominuje w polskiej gospodarce (rys. 6).

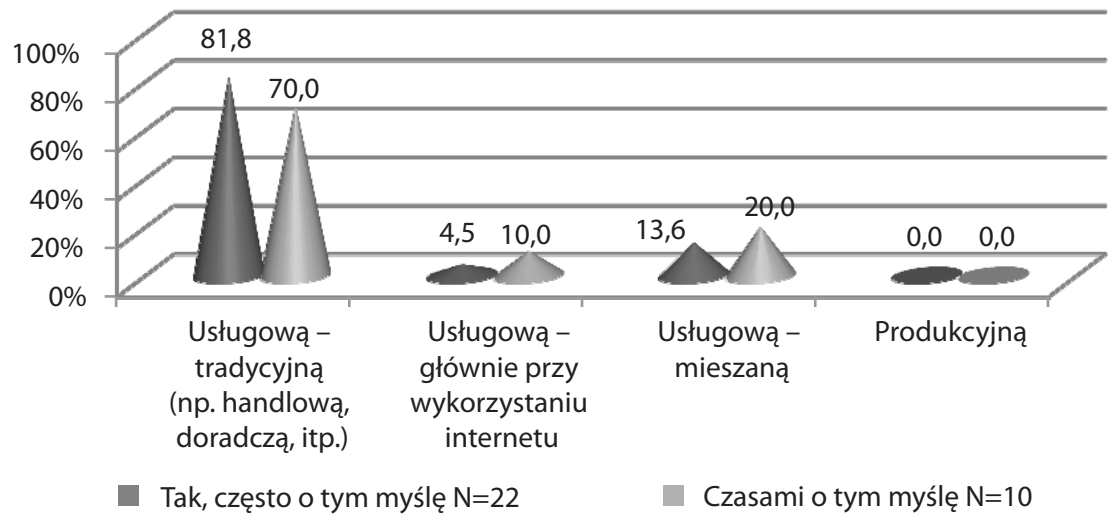

Rysunek 6. Rodzaj działalności gospodarczej, którą ankietowani chcieliby założyć Źródło: opracowanie własne na podstawie przeprowadzonych badań.

Inną kwestią jest termin, który według respondentów byłby najlepszy na założenie własnej firmy. Wśród osób, które myślą o tym najczęściej, najlepszym momentem byłby okres „zaraz po ukończeniu studiów” - takiej odpowiedzi udzieliło aż 45,5\% respondentów z tej grupy (rys. 7). 


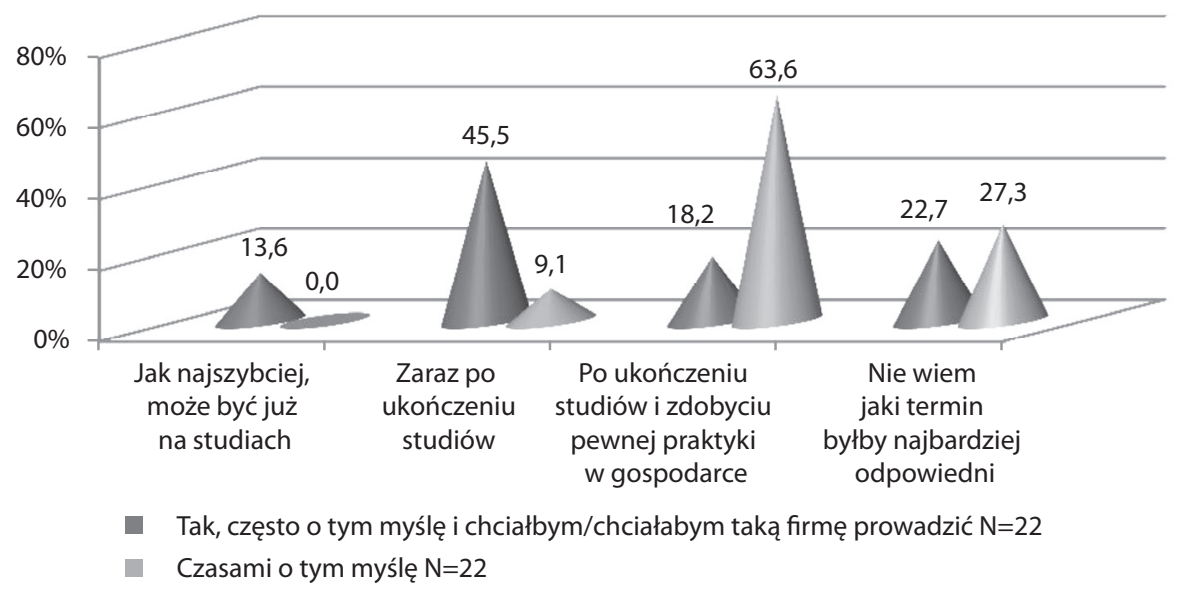

Rysunek 7. Najlepszy termin na założenie działalności gospodarczej według ankietowanych

Źródło: opracowanie własne na podstawie przeprowadzonych badań.

Osoby, które czasami myślą o uruchomieniu własnej firmy, są bardziej ostrożne i uważają, że najlepszym czasem jest okres „po ukończeniu studiów i zdobyciu pewnej praktyki w gospodarce" - na taki wariant wskazało aż 63,6\% respondentów z tej grupy. Osoby, które często myślą o założeniu własnej firmy (grupa A) są bardziej odważne i zdeterminowane, natomiast osoby, które czasami rozważają taką ewentualność (grupa B) są bardziej zachowawcze i uważają, że najpierw muszą zdobyć odpowiedni poziom umiejętności i wiedzy praktycznej, zanim ewentualnie zdecydują się na taki krok.

Najważniejszym czynnikiem dla podjęcia własnej działalności gospodarczej była chęć podejmowania wyzwań i ryzyka (czym więcej punktów procentowych ma dany wariant - tym jest on mniej istotny - rys. 8). Natomiast najmniej ważnym motywem uruchomienia działalności dla tej grupy osób była możliwość „wrzucania pewnych rzeczy w koszty”. Najważniejszym motywem dla osób z „grupy B” (osoby, które czasami myślą o założeniu własnej firmy) był fakt, że „działalność gospodarcza daje poczucie wolności”. Niewiele mniej ważna jest także możliwość zdobycia (dzięki prowadzeniu własnej działalności gospodarczej) większych dochodów.

Ankietowani zapytani o przeszkody powodujące lęk przed założeniem własnej firmy jako najważniejszą i najistotniejszą wskazali brak własnych środków na uruchomienie działalności gospodarczej (rys. 9). W obu zapytanych grupach odpowiedź ta uzyskała najmniejszą liczbę punktów, a zatem była to przyczyna bardzo ważna. Fakt ten wydaje się zrozumiały, bowiem uruchomienie własnej 


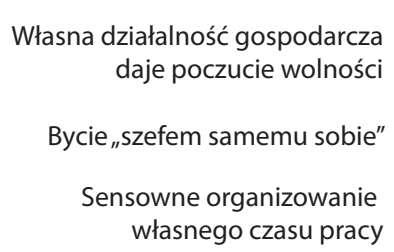

Własna działalność umożliwia zdobycie większych dochodów

Lubię wyzwania i ryzyko

Własna firma daje większy prestiż

Własna firma pozwala na nawiązanie licznych kontaktów

Własna firma pozwoli mi na rozwijanie zainteresowań

Możliwość „wrzucania pewnych rzeczy w koszty"

Inny powód

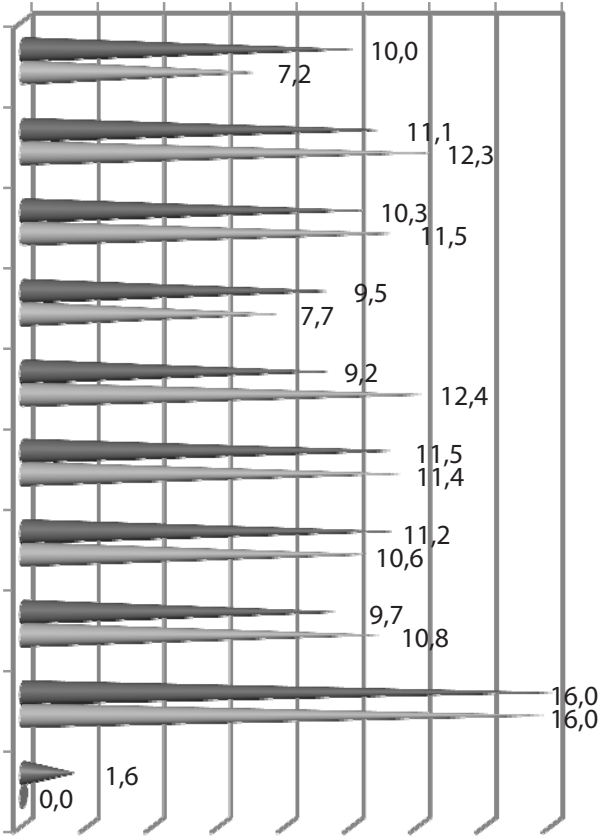

- Tak, często o tym myślę i chciałbym/chciałabym taką firmę prowadzić N=1020

- Czasami o tym myślę $\mathrm{N}=1000$

Ankietowani poproszeni zostali o przypisanie każdemu czynnikowi punktu od 1 do 9 , względnie przy dodaniu własnego powodu w opcji: Inny powód od 1 do 10, każdego punktu można użyć tylko raz - np. nie można przypisać dwóch 9 czy dwóch 8 itd., przy czym 1 - czynnik najważniejszy, 9 - czynnik ten nie ma znaczenia

Rysunek 8. Powody chęci założenia własnej firmy według ankietowanych Źródło: opracowanie własne na podstawie przeprowadzonych badań.

działalności gospodarczej zawsze (a przynajmniej prawie zawsze) wiąże się z nakładami inwestycyjnymi. Możliwe jest otrzymanie wsparcia, choćby z urzędu pracy, na rozpoczęcie własnej działalności gospodarczej, jednak zazwyczaj nie jest to pomoc wystarczająca. Obawa o sukces przedsięwzięcia wstrzymuje potencjalnych przedsiębiorców przed zaciąganiem kredytów lub pożyczek u rodziny. Kolejnymi, niewiele mniej ważnymi (według respondentów) przeszkodami, okazały się kłopoty z pozyskaniem kapitału obcego. Najmniej istotnymi przeszkodami dla ankietowanych są: skomplikowana procedura rejestracji przedsiębiorstwa oraz brak szkoleń i wsparcia doradczego ułatwiającego podjęcie decyzji o założeniu własnej firmy. Zdaje się, że do nadmiernej biurokracji w naszym kraju zostaliśmy już przyzwyczajeni (tym bardziej że procedura rejestracji własnej 


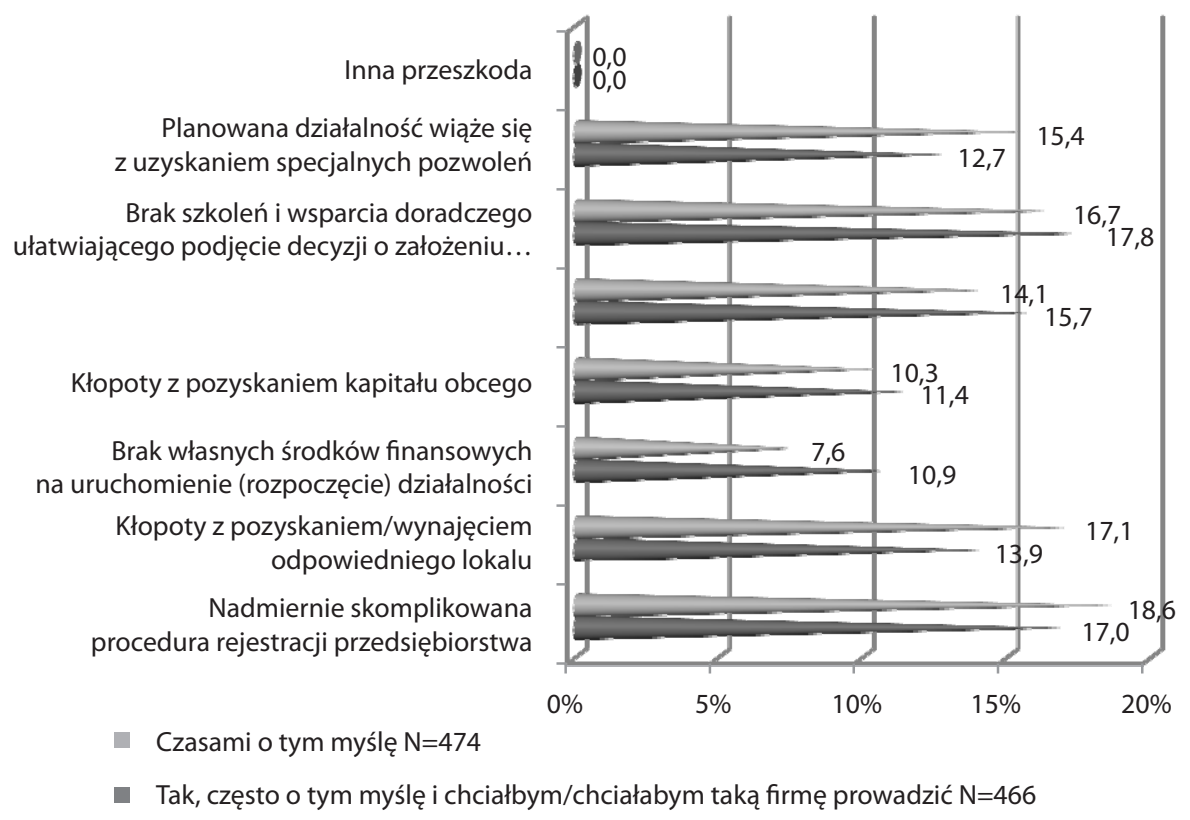

Ankietowani poproszeni zostali o przypisanie wagi poszczególnym przeszkodom, biorąc pod uwagę ich wpływ na podjęcie decyzji o założeniu firmy, przy czym 1 - przeszkoda bardzo ważna; 2 - przeszkoda ważna; 3 - przeszkoda umiarkowana; 4 - przeszkoda mało ważna; 5 - przeszkoda nieistotna. Punkty rozdysponowano w sposób dowolny tzn. można było przypisać dwie 5 , trzy 2 itd.

Rysunek 9. Przeszkody, które powodują obawę przed założeniem własnej firmy

Źródło: opracowanie własne na podstawie przeprowadzonych badań.

firmy została uproszczona - co nie znaczy, że w porównaniu z innymi krajami rozwiniętymi jest prosta), natomiast do szkoleń i specjalistycznego wsparcia doradczego nie zdążyliśmy się przyzwyczaić i nie potrafimy z niego korzystać (problemem może tu być także jakość tego rodzaju wsparcia).

Gdy respondenci „wczuli się” w rolę przedsiębiorcy, poproszeni zostali o wskazanie problemów, które przysporzyłyby im najwięcej kłopotów i nerwów podczas prowadzenia działalności gospodarczej. Ponownie okazało się, że dla obu zapytanych grup najważniejszym problemem jest pozyskanie środków finansowych na inwestycje oraz bieżące funkcjonowanie. Finanse kolejny raz okazały się kluczowym elementem. Ankietowani zdecydowanie uważają, że ani dobry pomysł, ani pracowitość nie są kluczem do sukcesu. Decydują przede wszystkim środki finansowe na start oraz rezerwa, która pomoże w bieżącym funkcjonowaniu (rys. 10). 
Kłopoty ze zbytem/znalezieniem klientów

Kłopoty z uzyskaniem rentowności całego przedsięwzięcia

Kłopoty z pozyskiwaniem środków finansowych na inwestycje i bieżące funkcjonowanie Kłopoty z pozyskaniem wykwalifikowanego personelu

Kłopoty administracyjno-podatkowe

Problemy ze ściąganiem należności od odbiorców

Kłopoty we współpracy z dostawcami towarów Słabo rozwinięta infrastruktura Inny problem

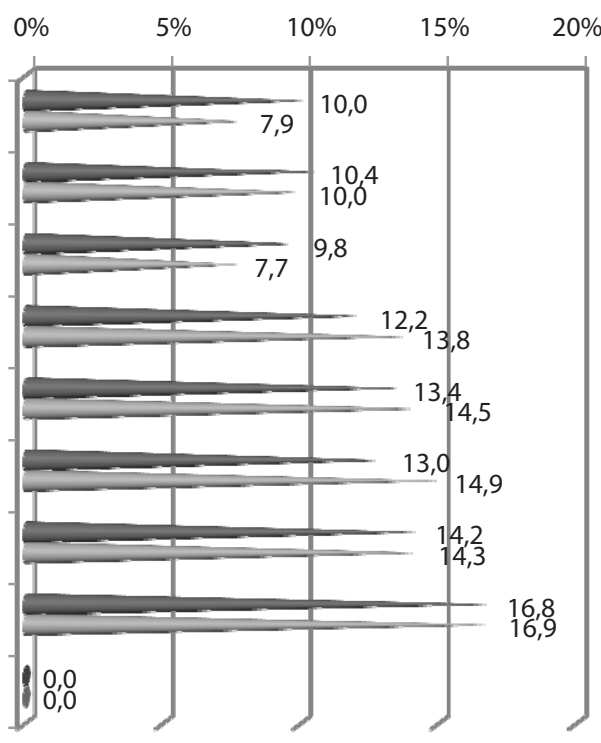

- Tak, często o tym myślę i chciałbym/chciałabym taką firmę prowadzić N=499

- Czasami o tym myślę $\mathrm{N}=509$

Ankietowani poproszeni zostali o przypisanie wagi poszczególnym przeszkodom, biorąc pod uwagę ich wpływ na podjęcie decyzji o założeniu firmy, przy czym 1 - przeszkoda bardzo ważna; 2 - przeszkoda ważna; 3 - przeszkoda umiarkowana; 4 - przeszkoda mało ważna; 5 - przeszkoda nieistotna. Punkty rozdysponowano w sposób dowolny, tzn. można było przypisać dwie 5 , trzy 2 itd.

Rysunek 10. Kłopoty i problemy, których obawiają się ankietowani w trakcie prowadzenia firmy

Źródło: opracowanie własne na podstawie przeprowadzonych badań.

Równie ważnym problemem jest pozyskanie klientów i związana z tym odpowiednio wysoka sprzedaż towaru bądź usługi. Obawy te są jak najbardziej słuszne, gdyż przy tak dużej konkurencji (w zasadzie w prawie każdej dziedzinie) i tak szerokim nasyceniu rynku przebicie się z towarem lub usługą jest bardzo trudne. Respondenci najmniej obawiają się kłopotów związanych ze słabo rozwiniętą infrastrukturą, ze ściąganiem należności od odbiorców oraz problemów we współpracy z dostawcami. 


\section{OCZEKIWANIA W ZAKRESIE WSPARCIA UDZIELANEGO POTENCJALNYM PRZEDSIĘBIORCOM}

Bardzo istotne jest pytanie o wsparcie, jakiego oczekiwaliby przyszli przedsiębiorcy zamierzający rozpocząć działalność własnej firmy (rys. 11). Nie dziwi zatem fakt, że podobnie jak w poprzednich pytaniach pomoc finansowa okazała się we wszystkich badanych grupach najważniejsza i najbardziej pożądana. Na drugim miejscu mile widziana okazałaby się pomoc doradcza oraz pomoc tzw. praktyków biznesu, a także współfinansowanie przedsięwzięcia biznesowego. Polska

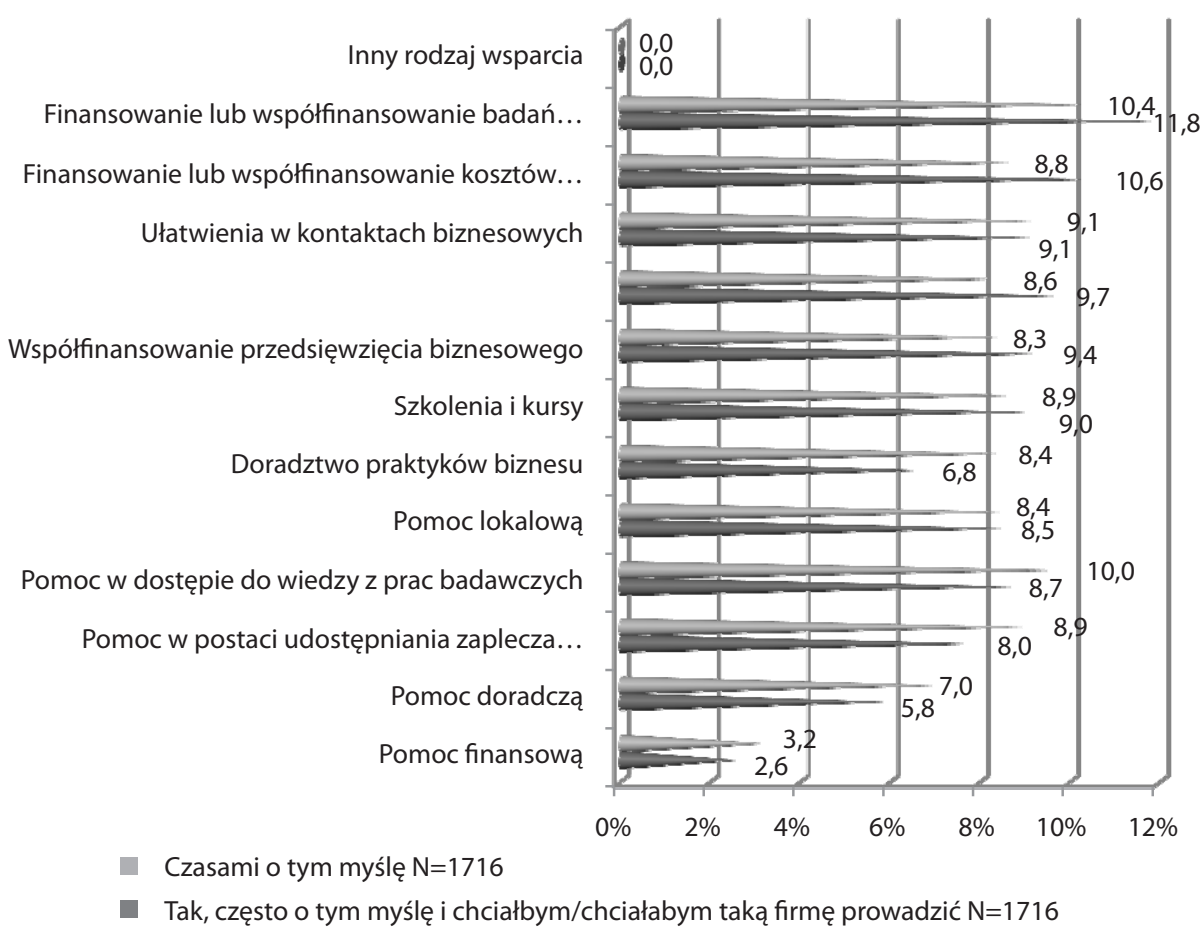

Ankietowani poproszeni zostali o przypisanie każdemu czynnikowi punktu od 1 do 12, względnie przy dodaniu własnego rodzaju w opcji: Inny rodzaj wsparcia od 1 do 13, każdego punktu można użyć tylko raz - np. nie można przypisać dwóch 9 czy dwóch 8 itd., przy czym 1 - czynnik najważniejszy, 12 - czynnik nie ma znaczenia

Rysunek 11. Rodzaj wsparcia oczekiwany przez rozpoczynającego działalność przedsiębiorcę

Źródło: opracowanie własne na podstawie przeprowadzonych badań. 
jako członek Unii Europejskiej korzysta z wielu programów tego typu. Ze środków pomocowych Unii Europejskiej organizowane są kursy i szkolenia doradcze dla kandydatów na przedsiębiorców (dotyczy to także środowiska akademickiego). Kończą się one często przyznaniem bezzwrotnych dotacji oraz nagrodami za najlepszy pomysł (biznes plan). Szkolenia te wprowadzają uczestników w świat biznesu, począwszy od napisania dobrego biznes planu, pomagają wybrać odpowiednią formę opodatkowania, uczą jak należy poprawnie zarejestrować działalność i dają wiele cennych rad, jak przetrwać na rynku. Prowadzą je zazwyczaj nie tylko wykształceni teoretycy, ale również doświadczeni praktycy (często biznesmeni z sukcesami).

Za najmniej oczekiwaną pomoc uznano finansowanie lub współfinansowanie badań marketingowych, zapewne dlatego, że najważniejsze jest zdobycie środków i wiedzy na temat prowadzenia firmy, a dopiero w kolejnych krokach zajęcie się analizą rynku, co wydaje się błędnym podejściem. Badania marketingowe często pozwalają odpowiednio zdiagnozować potrzeby rynkowe i wykorzystać wiedzę (uzyskaną z przeprowadzonych badań) do podejmowania trafnych decyzji.

\section{PODSUMOWANIE}

Przeprowadzone badania jednoznacznie pokazują, że chęci do prowadzenia własnej działalności gospodarczej są duże. Ponad $65 \%$ osób często i czasami rozważa na poważnie podjęcie tego ryzyka. Oczywiście nie bez obaw. Dla wszystkich ankietowanych pomoc finansowa była wskazywana jako ważny czynnik motywujący. Braki w kapitale początkowym, niezbędnym do uruchomienia własnej firmy, są jednocześnie głównym czynnikiem demotywującym. Na drugim miejscu wymieniano pomoc doradczą w postaci kursów i szkoleń, a także pomoc doradców biznesu (przede wszystkim praktyków). Te dwa czynniki, jako najbardziej oczekiwane przez potencjalnych przedsiębiorców, powinny być jak najszerzej wprowadzane i doskonalone, jeśli chcemy, aby „duch przedsiębiorczości” rozwijał się także w środowisku akademickim (które zaczyna przywiązywać coraz większą wagę do tej problematyki). Świadczą o tym zarówno zmiany w nowej ustawie o szkolnictwie wyższym, jak i liczne deklaracje instytucji i osób zarządzających polską nauką. Czy uda nam się dogonić w tej sferze rozwinięte gospodarki zachodnie, czas pokaże. Pamiętać jednak należy, że często przedstawianej za wzór amerykańskiej przedsiębiorczości akademickiej, rośnie silna konkurencja azjatycka. Dobrze by było, aby i Polska aktywnie włączyła się w ten wyścig, a polskie uczelnie stały się faktycznymi centrami rozwijania przedsiębiorczości i kreatywności. 


\section{LITERATURA}

Althus M. (2009), Die Anti-Harvards. Wie Bildungskonzerne Amerikas Hochschulwesen revolutionieren, LIT Verlag, Berlin.

Banerski G., Gryzik A., Matusiak K. B., Mażewska M., Stawasz E. (2009), Przed- siębiorczość akademicka. Raport z badań, Polska Agencja Rozwoju Przedsiębiorczości, Warszawa.

Barski R., Cook T. (2011), Metodyka identyfikacji projektów do komercjalizacji na wyższych uczelniach, Polska Agencja Rozwoju Przedsiębiorczości, Warszawa.

Cieślik J. (2008), Kształcenie w zakresie przedsiębiorczości na poziomie akademickim, „Edukacja”, nr 2 (102), Warszawa.

Cieślik J., Matusiak K. B, Guliński J., Skala-Poźniak A. (2011), Edukacja dla przedsiębiorczości akademickiej, Polska Agencja Rozwoju Przedsiębiorczości, Warszawa.

Katz J. A. (2003), The Chronology and Intellectual Trajectory of American Entrepreneurship Education 1876-1999, Journal of Business Venturing, vol. 18.

Kuratko D. F. (2004), Entrepreneurship education in the $21^{\text {st }}$ century: from legitimization to leadership, A Coleman Foundation White Paper, USASBE National Conference, (www.faculty.bus.olemiss.edu).

Matusiak K. B. (2010), Budowa powiazań nauki z biznesem $w$ gospodarce opartej na wiedzy. Rola i miejsce uniwersytetu $w$ procesach innowacyjnych, Szkoła Główna Handlowa, Warszawa.

Wissema J. G. (2005), Technostarterzy, dlaczego i jak?, Polska Agencja Rozwoju Przedsiębiorczości, Warszawa.

Wright M., Clarysse B., Mustar P., Lockett A. (2007), Academic Entrepreneurship in Europe, Edward Elgar, Cheltenham-Northampton.

\section{MOTIVES OF TAKING UP OF ECONOMIC ACTIVITIES AMONG STUDENTS}

A bstract: Identification of themes and concerns associated with establishing your own business among students is crucial to improving the teaching of the subject: "Entrepreneurship". The study clearly shows that the desire to run their own business are great. According to the research survey results, over $65 \%$ of students seriously considered taking that risk. The study clearly shows that the desire to set up their own business is great. For all respondents financial assistance was identified as an important motivating factor. Finances needed to start their own businesses, are also a major negative factor. In second place was indicated counseling, both in the form of courses, training and business support advisers (mostly practitioners). These two factors, as the most awaited by potential entrepreneurs, should be widely implemented and improved.

K e y w or d s : academic entrepreneurship. 